\title{
ICT use as a determinant of export activity in manufacturing and service firms: Multi-country evidence $^{*}$
}

\author{
Patricia Kotnik ${ }^{1}$ Eva Hagsten ${ }^{2}$
}

\begin{abstract}
The use of ICT is profoundly changing the way international business is done. The study aims to extend our understanding of export performance determinants by examining the relationship between different uses of ICT and export activity of firms for a range of European countries and doing this for a sample of larger manufacturing as well as service firms. A probit regression is used to examine whether firms that have a website, support online transactions or have a higher proportion of employees with access to broadband internet are more likely to export than similar firms that do not, controlling for a wide range of firm characteristics. This study is based on harmonized firm-level data provided by statistical offices of 11 EU countries to which the same empirical model was applied, providing results that are fully comparable across countries. The findings suggest heterogeneity amongst countries and specific characteristics of service firms. Whereas in some of the countries e-sales are being positively associated with the probability of exporting for firms from both sectors, having a website is only relevant for manufacturing firms and broadband-Internet-enabled employees are only relevant for service firms. ICT use does not appear to be of particular importance for firm export in a number of countries, opening up a question of what country characteristics can help explain the differences in the role ICT use plays in export performance.
\end{abstract}

Key words: Internet, ICT, e-sales, exports, service firms

JEL classification: F23, F14, O33

\footnotetext{
* Received: 07-12-2017; accepted: 12-06-2018

1 Assistant Professor, Faculty of Economics, University of Ljubljana, Kardeljeva ploscad 17, 1000 Ljubljana, Slovenia. Scientific affiliation: entrepreneurship, business economics. Phone: +38615892 579. Fax: +38615892-698.E-mail: patricia.kotnik@ef.uni-lj.si (corresponding author).
}

2 Statistics Expert, Statistics Sweden, Box 24300, 10451 Stockholm, Sweden (new affiliation: Swedish Agency for Economic and Regional Growth, Box 4044, 10261 Stockholm, Sweden). 


\section{Introduction}

Information and communication technology (ICT), and particularly the Internet, is profoundly changing the way international business is done. Online sales are used as an addition, or even a replacement, to physical channels of export distribution (Gabrielsson and Gabrielsson, 2011, Sinkovics et al., 2013). The large amounts of data generated when consumers use the Internet allow firms to gain new insights into customer behaviour through data mining (OECD, 2013, Rust and Huang, 2014). Firms can use the internet to search for information on new markets (Jones and Crick, 2004, Mathews and Healy, 2007) and to estimate market size and predict market shares (Matzler et al., 2013). Internet and the accompanying social media can be used to provide information to customers and can contribute to decreasing costs of doing business abroad (Arenius et al., 2005, Reuber and Fischer, 2011). It can also be used to support and enhance communication between the firm and the customer (Lohrke et al., 2006, Sultan and Rohm, 2004) and provide customer support (Prasad et al., 2001). To sum up, the use of ICT can enhance the information components of internationalization, lower the costs of entering foreign markets and doing business there, and increase the opportunities of sales to international customers. This calls for incorporating the ICT developments into theories explaining the internationalisation of firms (Overby and Min, 2001; Rhee, 2005) but this continues to be a challenge (Leonidou and Katsikeas, 2010). We want to add to this stream of research by investigating the relationship between different uses of ICT and export activity of firms for a range of European countries and by exploring differences between manufacturing and service firms.

In the era of new digital economy, a better understanding is needed of the relationship between the ways firms use this new technology and their international behaviour. The existing empirical evidence originating in international business and international trade literature (Clarke, 2008, Ganotakis and Love, 2011, MorganThomas and Jones, 2009, Raymond et al., 2015, Ricci and Trionfetti, 2012) points to a conclusion that a positive relationship exist between ICT and export performance. However, some of the relevant issues remain neglected. The studies usually investigate only single uses of ICT, for example online sales, and do not explore the simultaneous effect of different ICT uses on export performance. Only rarely do they control for a wide range of factors that might affect both, export behaviour and ICT use, and that can lead to detecting spurious relationship. Adding different aspects of the ICT use to the study of determinants of export performance of firms and controlling for a wide range of firm characteristics present the first major contribution of this paper. The aspects of ICT use include having a website, online sales, and proportion of workers with access to broadband internet.

The existing studies that include ICT and internet applications in the study of export performance have also been largely confined to manufacturing firms. Services firms are less likely to export, and also export less than manufacturing firms (Clarke, 
2008). However, service sector represents an important part of economic activity, with some 80 percent of gross domestic product in the United States and the EU originating in services (Borchert et al., 2013), and the firms in this sector are internationalising more and more quickly (Rodríguez and Nieto, 2012). To the best of our knowledge, no empirical studies using firm level data exist that examines the role of ICT use in export performance of services firms, with the exception of Clarke (2008). Contributing to this scarce literature is the second contribution of this paper.

And lastly, we base our work on firm-level data provided by the national statistical offices of $11 \mathrm{EU}$ countries where detailed adjustments were made to the data to achieve comparability across countries. Using various national sources of microdata, uniquely linked data sets were created, dominated by larger firms. An identically specified empirical model was then applied to this data, giving us an opportunity to examine empirical results on this topic that are fully comparable across countries. To do this for a range of countries with different economic, technological and cultural settings presents the third main contribution of our study. Overall, our main hypothesis is that ICT use is positively correlated with a firm's export activity and we aim to extend our understanding of this relationship by examining the differences between manufacturing and service firms and between countries, as well as between different uses of ICT.

Our results draw attention to the importance of the use of Internet in exporting of larger firms but they also reveal differences between sectors and between countries. The latter opens up a relevant question of why in some countries different uses of ICT affect the probability of a firm's exports whereas in others they do not. Policy initiatives can have a role here, aiming to reduce the obstacles to e-business and improve the ICT infrastructure, for example.

The paper is structured as follows. In the following section, we briefly review the empirical studies of the impact of ICT use on export performance. Section 3 presents the measurement of variables and the methods used. Section 4 describes the research setting and the data and presents descriptive statistics. The empirical results and their discussion are presented in Section 5. Finally, we discuss the implications of our study for the existing literature, along with the limitations of our study, in the last section.

\section{Literature review}

Despite the wide-reaching effects of ICT use, there is limited empirical research in international business and international trade literature investigating its relationship with the internationalization of firms. The evidence of research so far points to the conclusion that there exists a positive relationship between ICT 
and export performance. A strong direct relationship between reliance on ICT and rapid growth on international markets was found in a study by Morgan-Thomas and Jones (2009), studying newly internationalized SMEs. Raymond and others (2015) have shown that with the support of IT capabilities, the manufacturing SMEs transform external information into knowledge and thus contribute to internationalization performance. Two studies that worked with multi-country data that also included low and middle-income economies, have found that firms that use ICT are more likely to export than similar firms that do not (Clarke, 2008, Ricci and Trionfetti, 2012). However, exporting firms did not seem to export more when they had internet access (Clarke, 2008). Focusing on a subset of firms with specific characteristic may not lead to the same conclusions. A study of high-growth, hightech, relatively small firms has shown that e-commerce does nothing to boost entry of these firms into export markets; however, the intensity of their e-commerce use was associated with increased share of export sales in relation to total sales (Ganotakis and Love, 2011).

However, some of the relevant issues remain neglected. These studies have usually investigated only single functions of ICT, for example e-commerce, and did not explore the simultaneous effect of different uses of ICT on export performance. The exception to this is a study by Morgan-Thomas (2009) that has concluded that the key benefit of online contribution to export performance lies in supporting customer relationships and not in online sales. In addition to this, studies should control for factors that might affect both, export behaviour and ICT use, to avoid detecting spurious relationship between the two which might lead to misleading conclusions. For example, better performing firms might be more likely to be involved in exporting and more likely to have higher ICT use since they might have greater resources to invest in ICT (Clarke, 2008). Only rarely did studies control for a wide range of variables capturing firm performance (Ganotakis and Love, 2011, Ricci and Trionfetti, 2012). They have also been largely confined to focusing on a single country (Ganotakis and Love, 2011, Morgan-Thomas, 2009, Morgan-Thomas and Jones, 2009, Raymond and others, 2015). Focus on a single country is characteristic of exporting research in general, with North American and European countries being the most researched, and with UK providing the focus of most European studies (Leonidou and Katsikeas, 2010). Similar holds for the focus on manufacturing firms, where until recently the studies examining the services firms were less numerous.

Services that are being exported and can also be delivered digitally include accounting, auditing and book-keeping services, software related activities, research and design, advertising, travel services, arts, and entertainment, financial and investment services and more. Given the specific characteristics of services when compared to goods, more research is required that investigates the determinants of export performance of service firms (Conti et al., 2014, Pla-Barber and Ghauri, 2012, Sousa et al., 2008, Jaklič et al., 2012). The use of ICT is one such determinant. Internet 
can overcome many of the traditional problems that are inherent in the marketing of international services (Berthon et al., 1999) and the services that are transmittable via internet can now be traded almost without costs, irrespective of the location (Freund and Weinhold, 2004), increasingly permitting cross-border trade in services (Francois and Hoekman, 2010). Empirical results on a country and industry level have already offered evidence that internet has begun facilitating exports of services to the US, even as early as in the 1995-1999 period (Freund and Weinhold, 2002) and some have expected that the effect of internet should be larger for trade in services as compared to manufacturing (Freund and Weinhold, 2004). However, with the exception of study by Clarke (2008), no studies using firm-level data exist, to the best of our knowledge, that include ICT in the study of export performance of services firms.

In this study, we investigate the relationship between ICT use and firm's export behaviour. Firms can use the internet for different purposes: to support relationship marketing and collection of customer data, for information search and foreign market research activities, and to use it as a transaction and distribution channel. The main ICT tools that support such activities will include firm's website, access to internet and online transactions in the form of e-sales.

\section{Methodology}

\subsection{Measurement of variables}

\subsubsection{Dependent variable}

In this study, we look at the relationship between firms' ICT use and their export activity. The empirical model measures firms' export activity by export propensity, a categorical variable that indicates whether the firm exported or not. Export propensity has been used in a number of studies examining the determinants of firms' export behaviour (for example Gao et al., 2010, Gashi et al., 2014, Higon and Driffield, 2011, Roper et al., 2006, Serra et al., 2012, Wakelin, 1998).

\subsubsection{Independent variables}

We define three key independent variables: proportion of workers with access to broadband (a composite indicator based on the proportion of workers with access to Internet and on whether the firm has broadband); having a website (measured as a dummy variable); and online transactions (a dummy variable indicating whether the firm has e-sales or not).

Whereas the studies of the relationship between ICT and export performance usually capture only some of the uses of Internet (Clarke, 2008, Ganotakis and Love, 2011, 
Morgan-Thomas and Jones, 2009, Ricci and Trionfetti, 2012), our study comes closer to what we know is relevant for information technology (IT) capabilities to create competitive advantage. IT infrastructure is just a part of firm-specific IT resources (Bharadwaj, 2000) and it seems to be a competitive necessity but it is how firms use this infrastructure to create unique IT resources and skills that matters (Bhatt and Grover, 2005). Whereas we can classify having a website and e-sales in place as technological infrastructure, the proportion of workers with access to broadband is used as a proxy to capture the human capital aspect of IT resources; i.e., the use of IT infrastructure. Suggestive evidence has been found that broadband adoption in firms complements skilled workers in executing non-routine abstract tasks (Akerman et al., 2015) and some of these tasks can be assumed to support the firm's internationalisation efforts. Ideally, data would be at hand to better capture the various uses of Internet for the purposes of relationship marketing, for example, or the business skills of IT personnel that Bhatt and Grover (2005) suggest as relevant. However, this is not possible when using the data gathered by statistical offices with standardised questionnaires. The data used in our study does offer a strong advantage though: that of objective data on firm performance and other firm characteristics.

\subsubsection{Control variables}

Determinants of export performance are today a well-researched topic but the research remains fragmented, still lacking a widely accepted model of export determinants, and uses a wide variety of measures (Sousa et al., 2008). Recent studies address this by integrating resource-, institution-, and industry-based views in the examination of factors that influence firms' export performance (Gao et al., 2010). Furthermore, they extend the determinants of exporting that draw on international business studies with those from trade theories of heterogeneous firms that originate in economics literature, thus providing a fuller account of these determinants (Yi and Wang, 2012). A recent stream of literature on firm heterogeneity and international trade is based on work by Melitz (2003) and others. Theoretical studies and empirical work that followed have placed special focus on the interaction of sunk costs of entering export markets and firm productivity (Bernard and Jensen, 2004). A firm's export entry decision will be determined by a combination of the two, and only more productive firms will self-select into export markets. Empirical studies have extended these two firm characteristics to include factors such as human capital, capital intensity, size, age, foreign ownership and others, and results show that some, if not all, variables are strongly connected with export market entry (Greenaway and Kneller, 2007).

Building on some prior studies (Bernard and Jensen, 2004, Gashi et al., 2014, Yi and Wang, 2012) we select controls that are considered strongly related to export performance at the firm level: a set of variables relating to firms' productive resources, and two control variables pertaining to firms' innovation activities, whereas the rest 
are variables for potential effects of factors such as firm age, foreign ownership, past exporting experience, industry and year dummies and industry export intensity.

Specifically, we control for labour productivity, capital-labour ratio, firm size (i.e., number of employees), both product and process innovations (measured by a dummy variable), and human capital of the firm. The method of measuring human capital depends on the availability of data in each country. In some, the data allowed us to differentiate between ICT-intensive and non-ICT-intensive human capital, to further examine the ICT-related aspects of firms' resources. ICT-intensive human capital is proxied by the proportion of employees with post-upper secondary education in maths, physics, engineering, and IT whereas non-ICT-intensive human capital refers to employees with post-upper secondary education in other fields of education. In one of the countries where the data on educational levels did not include these fields, a proportion of employees with post-upper secondary education is used. Where data on educational achievement was not available, wages were used as a proxy for human capital. We also control for firm age (i.e., the number of years of operation since establishment) and foreign ownership (defined as a dummy variable). Two control variables relate to exporting. The first refers to whether the firm exported or not in the previous year. International experience of the firm is widely used as a firmspecific determinant of export performance (Sousa et al., 2008) and we use the lagged export status as a proxy. The second control variable captures spillover effects due to exporting activities of firms in the industry the firm belongs to. We include this variable to capture industry-based determinants of export behaviour, similar to Gao and others (2010) who have measured it in the same way (i.e., as \% of exporters in a specific industry) and have found it to be a relevant determinant of firms' export propensity. Yi and Wang (2012) have also built on research that indicates that firms enjoy spillover effects from their proximity to other firms. Their results confirmed this, indicating that industry-specific proximity to other exporters helps firms to reduce the costs of entering foreign markets. Year and industry dummies are included in our estimations to control for time and industry fixed effects.

\subsection{Methods}

Given the nature of our dependent variable, measured as export propensity, we have used a probit regression. A Maximum likelihood procedure is used to estimate the following Probit model:

$$
X D_{i t}^{*}=\beta_{0}+\beta_{1} E X_{i t-1}+\beta_{2} R_{i t-1}+\beta_{3} C_{i t}+\beta_{4} I_{i t-1}+\beta_{5} I C T_{i t-1}++\beta_{6} H K_{i t-1}+\beta_{7} E X_{\text {Spil }}+\beta_{8} S+\varepsilon_{i t}
$$

$X D_{i t}{ }^{*}$ represents the probability to export, and the observed variable $X D_{i t}$ takes on the value of 1 if the firm is an exporter, otherwise 0. Subscripts $i$ and $t$ denote firm and time. Prior exporting experience is described by the lagged variable $E X_{i t-1}$, whose coefficient is usually interpreted as evidence of sunk costs. $R_{i t-1}$ indicates the 
productive resources (labour productivity, capital-labour ratio and firm size) and $C_{i t}$ relates to other characteristics of the firm (age and foreign ownership). $I_{i t-1}$ is a set of indicators of innovation activities (dummy for product and process innovation). Additionally, $I C T_{i t-1}$ reflects the set of ICT indicators and $H K_{i t-1}$ illustrates the proportion of highly skilled human capital in firms, including ICT-intensive human capital. In case information about schooled human capital is missing, wages are used as a proxy. Spillovers from other export activities within the same industry is captured by EX_Spill $l_{i t}$, and $S_{i t}$ is a vector of industry and year dummies.

Pooled and unbalanced samples are used to estimate our model for each of the countries separately (more on the research setting can be found in the next section). Given that studies have identified reciprocal causal relationships between the determinants and exports (see, e.g., Filipescu and others (2013) for a study on reverse relationship between exports and innovation, and Wagner (2007) on exports and productivity) we may face an endogeneity problem. To deal with the problems of causality, we use lagged values of most of the independent variables (with the exception of export spillovers and such firm characteristics as age and foreign ownership). This strategy is often used in other studies to deal with this problem (e.g. Bernard and Jensen, 2004, Wang et al., 2013). A one-year lag is used in this study.

We are aware that determining causality would ideally require a more rigorous econometric approach; however, this would be more suitable for investigation on a smaller scale with fewer countries and was not possible in the research setting underlying this study. Due to the nature and size of available data sets, it was also not possible to include firm fixed effects in the model (the data sets that include innovation as well as ICT use variables resulted in a small unbalanced panel of firms that is not large enough for this purpose). The main advantage of our empirical analysis, in addition to also including service firms, is that it allows us to compare indicators across countries based on harmonised data sets and identically performed estimating procedures. In this way, it gives useful insights about the relationship between export behaviour and its various presumed determinants but it does not allow us to measure effects.

\section{Empirical data and analysis}

The data used in this study have been made available through the EU-funded ESSLait Project in which statistical offices from a number of European countries have participated. Firm-level data is routinely gathered by statistical offices, for the purposes of processing of data into statistical information. For the purposes of this project, the statistical offices linked various data sets of microdata to build all-encompassing data sets to be used for analysis, in each of the 14 countries that took part in this project. A range of statistical offices' sources was included for this 
purpose: business, trade and education registers (which contain information on all firms) as well as the surveys on production, ICT usage and innovation activities in firms (which include information on a sample of firms). In the case of surveys, the sizes of the national samples differ, but all samples are representative of industrysize strata. Among the 14 countries, a few had to be excluded because of uneven data coverage, which resulted in 11 countries being included in the analysis (Denmark, Finland, France, Ireland, Luxembourg, Netherlands, Norway, Poland, Sweden, Slovenia and the United Kingdom).

Since statistical offices only allow access to data inside the safe premises of the statistical offices themselves, it was not feasible to stack the data into one single cross-country data set. An alternative method to reach the data was thus needed. The project chose to apply the means of the Distributed Microdata Approach (Bartelsman et al., 2016), where code modules for analyses and aggregation of indicators have been run on all national firm-level data sets locally, on the premises of the statistical office. Summary statistics, moments and analytical results were automatically aggregated by this common protocol and pooled into national results. The researchers then only had access to these results. The code modules that were run on the data were many (the export theme was just one of them). The length and complexity of the code itself, together with the project's schedule and a large number of countries involved, meant that only a few runs of the code were possible and the possibilities for more complex econometric analysis that would require additional runs were very limited. However, this research setup also has its benefits since it relied heavily on careful metadata analysis as a means to harmonise the underlying data sets across countries. The process resulted in data of high quality that is comparable across countries, a strong advantage of our study.

A description of the measures used in the estimation and their sources is presented in Table 1. Nominal values have been deflated by EU KLEMS Growth and Productivity Accounts or World Input-Output Database price series where needed, on the level of 2-digit Statistical classification of economic activities in the European Community Rev. 1.1. For each of the countries, we have a pooled and unbalanced sample sourced from data sets spanning over a number of years (the actual period depends on the availability of data in each country, ranging from 2001 to 2010). ${ }^{3}$ The data sets include manufacturing and services firms (industries with codes 15-37 and 50-99), exclusive of energy, water and construction (industries 4045). Industries 75 (Public administration and defence; compulsory social security) to 99 (Extra-territorial organizations and bodies) are partially covered. Descriptive statistics and results are shown for manufacturing and market services sectors from

\footnotetext{
3 The period covered in each of the countries is as follows: Denmark: 2006-2010, Finland: 20022010, France: 2001-2010, Ireland: 2004-2010, Luxembourg: 2003-2010, Netherlands: 2002-2010, Norway: 2002-2010, Poland: 2003-2010, Sweden: 2001-2010, Slovenia: 2003-2010, and the United Kingdom: 2002-2010.
} 
which ICT producing industries were excluded (the samples for ICT producing industry are not large enough for probit analysis). ${ }^{4}$

Table 1: Measurements of variables and sources of data

\begin{tabular}{|c|c|}
\hline Variable & Measure and source of data \\
\hline Export decision* & Exporter $=1,0$ otherwise (VAT, Trade statistics) \\
\hline Firm size & Number of full time employees or head counts (BR or PS) \\
\hline Labour productivity & Nominal sales per employee (PS) \\
\hline Capital-labour ratio** & Capital stock or book value per employee (PS) \\
\hline Product innovation & Product innovator $=1,0$ otherwise (IS) \\
\hline Process innovation & Process innovator $=1,0$ otherwise (IS) \\
\hline Human capital: & Either: \\
\hline - Wages; or & Total wage bill per employee (PS) - if educational achievement n.a. \\
\hline $\begin{array}{l}\text { - ICT-intensive } \\
\text { human capital } \\
\text { and }\end{array}$ & $\begin{array}{l}\text { Proportion of post upper secondary ICT educated employees } \\
\text { (Education Register, Occupation register or IS, ISCED: maths, } \\
\text { physics, engineering or ICT) }\end{array}$ \\
\hline $\begin{array}{l}\text { - Non-ICT intensive } \\
\text { human capital; or }\end{array}$ & $\begin{array}{l}\text { Proportion of post upper secondary generally educated } \\
\text { employees }\end{array}$ \\
\hline - Human capital & $\begin{array}{l}\text { Proportion of employees with post upper secondary education - } \\
\text { if field of education n.a. }\end{array}$ \\
\hline Website & Having a website $=1,0$ otherwise $(\mathrm{EC})$ \\
\hline $\begin{array}{l}\text { Online transactions } \\
\text { (e-sales) }\end{array}$ & $\begin{array}{l}\text { Selling through computer networks (websites or Electronic } \\
\text { Data Interchange) }=1,0 \text { otherwise (EC) }\end{array}$ \\
\hline $\begin{array}{l}\text { Proportion of workers } \\
\text { with access to broadband }\end{array}$ & $\begin{array}{l}\text { Proportion of internet-enabled employees with access to } \\
\text { broadband (EC) }\end{array}$ \\
\hline Age & Firm age in years (BR) \\
\hline Foreign ownership & Foreign ownership $=1,0$ otherwise $(\mathrm{BR}$ or PS) \\
\hline Export spillovers & $\begin{array}{l}\text { Ratio of exporters to total number of firms in an industry } \\
\text { (2-digit NACE); (Trade statistics, VAT) }\end{array}$ \\
\hline $\begin{array}{l}\text { Time fixed effects } \\
\text { Industry fixed effects }\end{array}$ & $\begin{array}{l}\text { Year (BR, PS, IS, EC) } \\
\text { Industry 2-digit code (BR) }\end{array}$ \\
\hline
\end{tabular}

Note: *For Netherlands and Norway, data is available only for trade in goods, whereas for other countries the data on exports include that of services. ** Not available for all countries.

$\mathrm{BR}=$ business register, $\mathrm{PS}=$ production survey, structural business statistics or similar, $\mathrm{EC}=\mathrm{E}$-commerce survey (ICT usage in firms) and IS = Innovation survey (community innovation survey). Data on exports originate from either the value added tax register (VAT) or from the trade statistics.

Source: ESSLait data sets, based on data provided by participating statistical offices

$\overline{4}$ For the purpose of the ESSLait project, the linked data sets were split using the EU KLEMS Growth and Productivity Accounts alternative industry hierarchy which separates the ICT-producing firms (in which firms from electrical machinery, post and telecommunications industries are classified) from the manufacturing and service firms that are ICT users. 
The linking of various national firm-level sources of data allows us to use the data sets that were previously not available for analysis of the relationship between export behaviour and ICT use. To estimate our model, all the sources listed in Table 1 needed to be merged, to come up with a matched data set of firms. Statistical offices gather data on innovation and ICT usage (and in some countries also the production statistics) with the use of surveys. When more than one sample survey is used to create a data set, it is reasonable to assume that the representativeness can be affected. The sampling strategies underlying the microdata in use here are developed by the national statistical agencies with the purpose of giving good macro estimates, meaning that emphasis is placed on including as much of the production value as possible rather than all firms. Also, the efforts of the national statistical offices to limit the response burden for smaller firms have, especially in some of the countries, resulted in smaller overlap of the samples from different data sets. As a result there is a certain bias towards larger firms.

Because of the sampling strategies, the firms in this uniquely linked data set are not only larger but also more innovative, with higher human capital and higher labour productivity when compared with the population of firms. Our sample also somewhat overestimates the use of ICT as measured by the chosen variables, especially so in the case of e-sales. In Table 2, means for the main variables used in the analysis are reported for each of the 11 countries, for the last available year in the data sets. In the case of the three measures of ICT use, we can observe that in the case of firms that have websites, the variable reaches saturation in countries with the highest ICT use. This is not yet the case when it comes to broadband Internet-enabled employees and e-sales. In comparing manufacturing and services, the biggest difference is evident in the case of proportion of employees with broadband access, not surprisingly. Table 2 also reveals the differences across European countries in the firms' uptake of the ICT. However, these values are not directly comparable between countries for the purposes of ranking the countries, since the observations are not weighted to give representative results. 


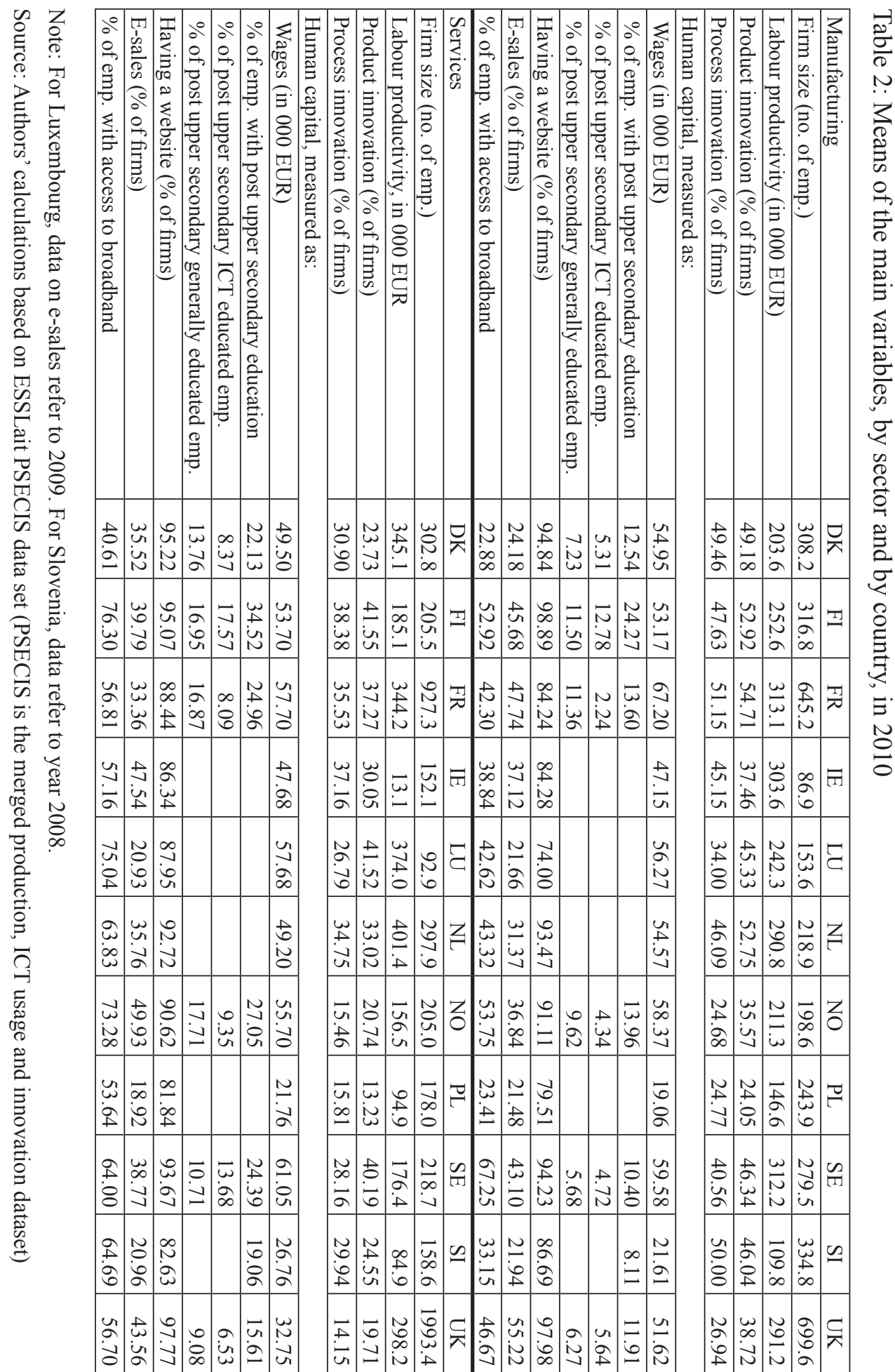


Tables 3 and 4 show ICT use of exporters and non-exporters and the share of exporters in the sample, for both of the sectors. ${ }^{5}$ Based on the information in these two tables, exporters are found to have higher ICT use compared to firms that do not export, on average.

Table 3: Information and communication technology use of exporters and nonexporters, manufacturing, 2010

\begin{tabular}{|l|r|r|r|r|r|r|r|}
\hline \multirow{2}{*}{ Country } & \multicolumn{2}{|c|}{ Having a website } & \multicolumn{2}{|c|}{ E-sales } & \multicolumn{2}{c|}{$\begin{array}{c}\text { \% of emp. with } \\
\text { access to broadband }\end{array}$} & $\begin{array}{c}\text { Share of } \\
\text { exporters }\end{array}$ \\
\cline { 2 - 9 } & Exporters & $\begin{array}{c}\text { Non- } \\
\text { exporters }\end{array}$ & Exporters & $\begin{array}{c}\text { Non- } \\
\text { exporters }\end{array}$ & Exporters & $\begin{array}{c}\text { Non- } \\
\text { exporters }\end{array}$ & \\
\hline DK & 0.95 & 0.88 & 0.22 & 0.21 & 0.22 & 0.22 & 83.7 \\
\hline FI & 0.99 & 0.93 & 0.38 & 0.26 & 0.52 & 0.46 & 70.5 \\
\hline FR & 0.86 & 0.62 & 0.43 & 0.17 & 0.43 & 0.30 & 75.9 \\
\hline IE & 0.89 & 0.76 & 0.36 & 0.26 & 0.39 & 0.34 & 64.4 \\
\hline LU & 0.74 & 0.60 & 0.17 & 0.19 & 0.41 & 0.39 & 85.8 \\
\hline NL & 0.94 & 0.93 & 0.30 & 0.22 & 0.44 & 0.34 & 93.6 \\
\hline NO & 0.92 & 0.81 & 0.35 & 0.37 & 0.54 & 0.45 & 72.4 \\
\hline PL & 0.89 & 0.68 & 0.30 & 0.11 & 0.26 & 0.20 & 55.2 \\
\hline SE & 0.95 & 0.94 & 0.47 & 0.22 & 0.67 & 0.64 & 84.4 \\
\hline SI & 0.90 & 0.61 & 0.23 & 0.10 & 0.36 & 0.28 & 72.7 \\
\hline UK & 0.98 & 0.93 & 0.58 & 0.46 & 0.50 & 0.45 & 74.1 \\
\hline
\end{tabular}

Note: Data for E-sales for Luxembourg refer to 2009.

Source: Authors' calculations based on ESSLait PSEC data set (PSEC is the merged production and ICT usage dataset)

In the case of manufacturing firms (Table 3), the most substantial differences can be found in the propensity to have a website and engage in online sales, whereas for services firms (Table 4) the most striking difference occurs in the share of broadband-enabled employees. The data in these tables also show that the variance across countries, in ICT use of exporters as well as non-exporters, can be substantial.

\footnotetext{
5 The comparison between exporters and non-exporters is drawn on a data set different to the one used for the regression estimates. Due to disclosure issues that the national statistical offices insisted upon, sample descriptives by export status were not possible to disclose since the resulting data sets were deemed too small and thus possibly revealing. Tables 3 and 4 are based on a data set merging ICT usage and production survey. Since the firms included in our probit analysis will be larger, more productive and with above-average ICT use, we can expect that the differences between exporters and non-exporters in our sample will be smaller than observed here.
} 
Table 4: Information and communication technology use of exporters and nonexporters, services, 2010

\begin{tabular}{|l|r|r|r|r|r|r|r|}
\hline \multirow{3}{*}{ Country } & \multicolumn{2}{|c|}{ Having a website } & \multicolumn{2}{|c|}{ E-sales } & \multicolumn{2}{c|}{$\begin{array}{c}\text { \% of emp. with } \\
\text { access to broadband }\end{array}$} & Share of \\
\cline { 2 - 8 } & Exporters \\
& Exprers & $\begin{array}{c}\text { Non- } \\
\text { exporters }\end{array}$ & Exporters & $\begin{array}{c}\text { Non- } \\
\text { exporters }\end{array}$ & Exporters & $\begin{array}{c}\text { Non- } \\
\text { exporters }\end{array}$ & \\
\hline DK & 0.94 & 0.88 & 0.34 & 0.28 & 0.42 & 0.28 & 53.8 \\
\hline FI & 0.99 & 0.95 & 0.53 & 0.25 & 0.85 & 0.74 & 24.2 \\
\hline FR & 0.87 & 0.67 & 0.35 & 0.18 & 0.61 & 0.38 & 41.1 \\
\hline IE & 0.92 & 0.75 & 0.44 & 0.29 & 0.72 & 0.39 & 22.4 \\
\hline LU & 0.81 & 0.67 & 0.18 & 0.15 & 0.68 & 0.50 & 71.7 \\
\hline NL & 0.92 & 0.90 & 0.38 & 0.31 & 0.68 & 0.63 & 76.2 \\
\hline NO & 0.94 & 0.76 & 0.53 & 0.37 & 0.81 & 0.64 & 35.4 \\
\hline PL & 0.91 & 0.72 & 0.27 & 0.14 & 0.65 & 0.40 & 22.8 \\
\hline SE & 0.93 & 0.95 & 0.45 & 0.30 & 0.65 & 0.66 & 56.3 \\
\hline SI & 0.90 & 0.77 & 0.30 & 0.20 & 0.67 & 0.56 & 32.3 \\
\hline UK & 0.98 & 0.97 & 0.36 & 0.50 & 0.82 & 0.53 & 26.0 \\
\hline
\end{tabular}

Note: Data for E-sales for Luxembourg refer to 2009.

Source: Authors' calculations based on ESSLait PSEC data set (PSEC is the merged production and ICT usage dataset)

Tables 5 and 6 report the results from the probit regression estimated for each national sample, for manufacturing and services respectively. ${ }^{6}$ In our results for the manufacturing sector, a positive and statistically significant coefficient is obtained for the three measures of ICT use in our model in a number of countries but not all of them. Even after controlling for firm and industry characteristics, firms with a website were more likely to export than firms without it in 4 out of 11 countries (Ireland, Luxembourg, Poland and Slovenia). Next, in Poland, Sweden and Slovenia, there is strong evidence of e-sales being positively associated with the probability of exporting. Lastly, no evidence can be found that firms with a higher proportion of broadband-Internet-enabled employees are more likely to export.

For service firms (Table 6), firms with e-sales tend to be more likely to export in 2 countries out of 8 (Sweden and Slovenia). It is interesting to note that Sweden and Slovenia are countries where e-sales seem to be important for both manufacturing and service firms. The coefficient of the broadband Internet-enabled employees' variable is highly statistically significant and positive in Poland and the UK. It is worth noting that this relationship can be found even after controlling for the firm's human capital. Having a website does not seem to be relevant for the export propensity.

\footnotetext{
${ }^{6}$ Data on trade in services is available only for 8 of the countries.
} 
Patricia Kotnik, Eva Hagsten - ICT use as a determinant of export activity...

Zb. rad. Ekon. fak. Rij. • $2018 \cdot$ vol. $36 \cdot$ no. $1 \cdot 103-128$

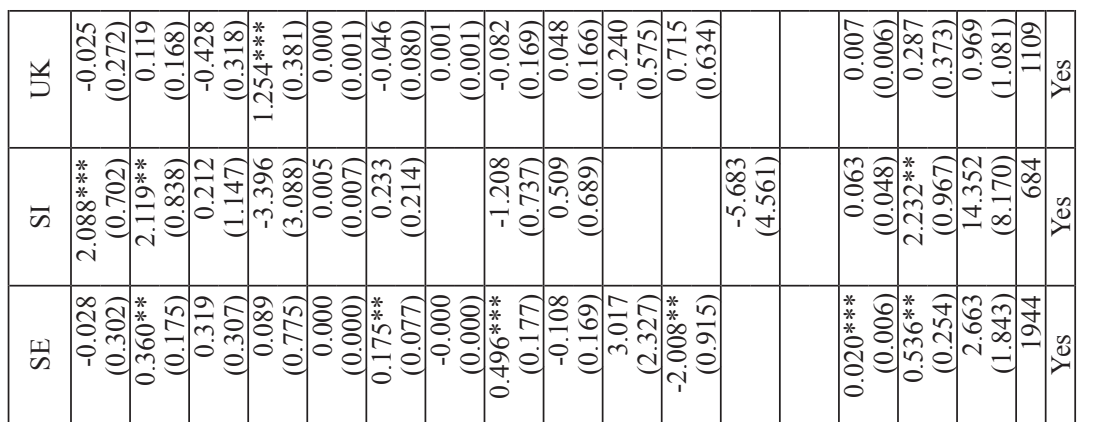

* ส

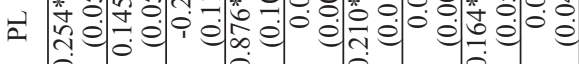

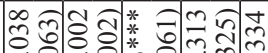

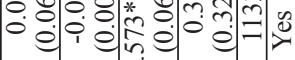

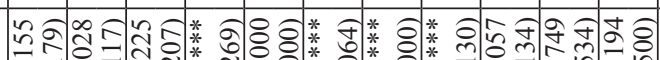

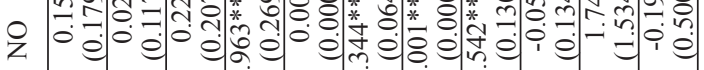

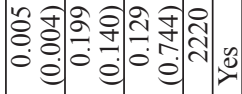

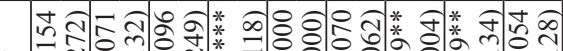

塁

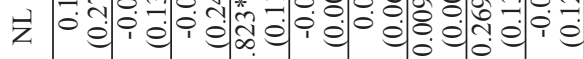

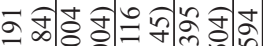

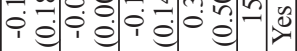

*

马

సี่

:

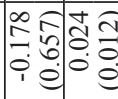

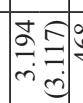

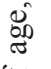

फ

.율

己े

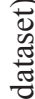

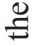

爱

\#色

$\therefore$

○ 80

¿

๘)

* สิษ

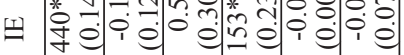

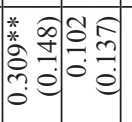

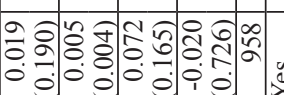

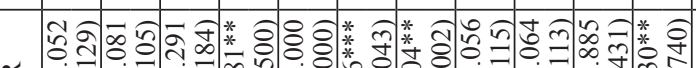

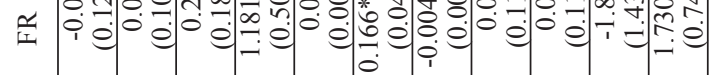

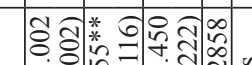

(2)

กี

$\frac{0}{0}$

పี

$\stackrel{8}{*}$

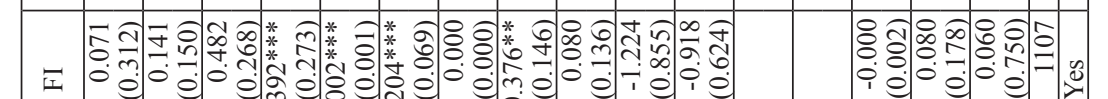

e el ma

-

穿

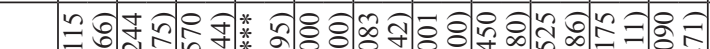

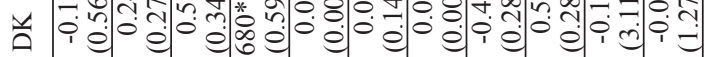

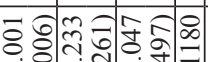

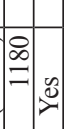

을

\begin{tabular}{l|l|l}
\hline &
\end{tabular}

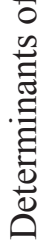

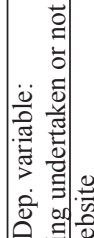

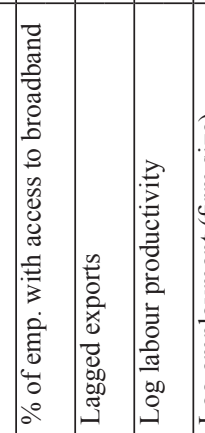

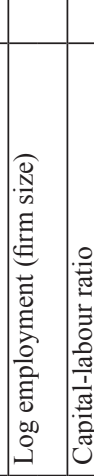

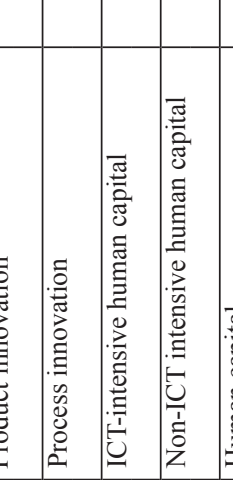

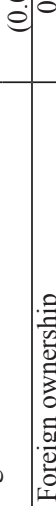

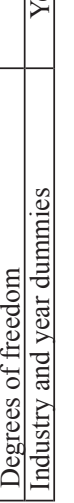

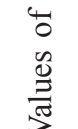

$>\quad$

ㅁ.

$\nabla$ t

\%

* 元

ㅇ. 芩

可

* 흐 떠

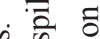

D)

表

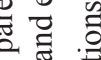

$\exists$ 으 족

कํㅠ

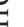

(2)

胥

.

is

$\ddot{8}$

응 
Patricia Kotnik, Eva Hagsten • ICT use as a determinant of export activity... Zb. rad. Ekon. fak. Rij. • $2018 \cdot$ vol. $36 \cdot$ no. $1 \cdot 103-128$

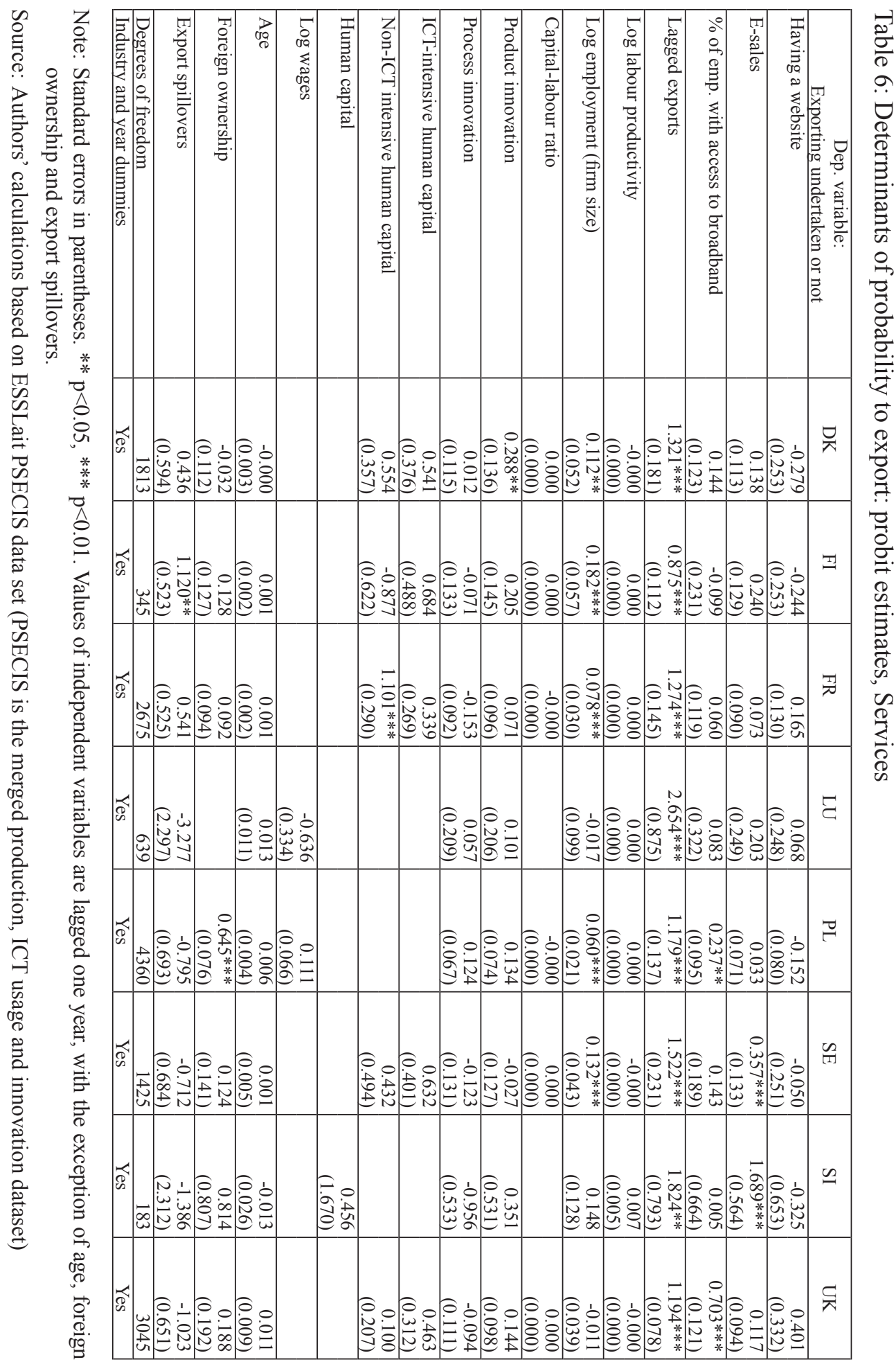


With regard to control variables, there is strong evidence of lagged exports and firm size being positively associated with the probability of exporting, for both sectors. For service firms in all countries it holds that firms that have export experience in the previous year are more likely to export. This also holds for manufacturing firms in most of the countries. Larger firms are more likely to export in almost half of the countries examined in the case of manufacturing and in 5 countries out of 8 for services firms. In terms of the other control variables, it seems that, for manufacturing, firms that have introduced a product innovation tend to be more likely to export (this holds true for 6 countries out of 11). The relevance of product innovation is much less pronounced for firms from the service sector (where coefficients for this variable are statistically significant in only 1 country). Process innovation does not seem to be related to the export propensity of firms. Level of labour productivity is positively related to export propensity in some but not all countries in the case of manufacturing firms. Foreign-owned manufacturing firms are more likely to export in France, Poland, Sweden and Slovenia whereas foreignowned service firms are more likely to export only in Poland. There is strong evidence of a positive relationship between human capital (measured as non-ICT intensive human capital) only in France, for firms from both sectors. In the case of Swedish manufacturing firms, the coefficient on this variable is negative. And lastly, only in the case of services firms in Finland does a positive relationship exist between export spillovers and export propensity. Firms that belong to industries with a higher proportion of exporters thus do not seem more likely to export, in most countries.

\section{Results and discussion}

Our results for the manufacturing sector suggest that in some of the countries (4 out of 11), firms with a website are more likely to export than firms without it. For these countries, the result is in line with the benefits a website can bring, such as using it to provide information, stimulate customer awareness and collect data on the customers. It is also in line with a study by Ricci and Trionfetti (2012) showing that firms are more likely to export if they have a website and use email. When trying to interpret this result in the context of multi-country comparison, we suggest that having a website could be relevant for exports only in those countries where this ICT tool has not yet reached saturation. In our samples, the proportion of firms with a website is the lowest in these 4 countries where a positive relationship can be found (with the addition of France), as can be seen from the descriptive statistics in Table 2. Once the saturation is reached and almost all firms have a website, other ICT tools might become more important. An alternative explanation is also possible. In the countries with high saturation, the variation in the share of firms that have a website might be too small, leading to a statistically insignificant result. 
In three of the countries, strong evidence can be found of e-sales being positively associated with the probability of exporting. This suggests there are benefits to online sales as a channel of distribution that can reach foreign customers and is consistent with the findings of similar studies (such as Wang et al., 2011). However, results for the remaining countries where no such evidence was found seem more in line with research that has found no evidence of an effect on export performance (Morgan-Thomas, 2009) or has emphasised that using online sales as an alternative to physical presence on a foreign market does not lead to higher performance (Sinkovics et al., 2013). No evidence can be found on the relevance of broadbandInternet-enabled employees for export propensity.

Overall, for some countries, the findings are in line with the conclusions of previous studies that suggest a positive association between ICT use and export performance. The results also indicate that even such a simple ICT tool as a website seems to allow the firms in some countries to support their internationalisation efforts. However, there is no clear relationship between ICT use and export propensity in 6 of the countries which suggests that the nature of this relationship does not always hold. It is also worth noting that in some of the countries more than one ICT usage variable is shown to be associated with the probability of exporting, with the patterns of relevant ICT uses differing between countries, whereas in others only one measure of ICT use is statistically significant.

In the case of service firms, having a website does not seem to be relevant for the export propensity, whereas e-sales are, but only in 2 out of 8 countries. In Poland and UK, the coefficient of the broadband-Internet-enabled employees' variable is highly statistically significant and positive, even after controlling for firm's human capital, which seems to be in line with the benefits of access to Internet for internationalisation (Clarke, 2008) that can range from new information and thus new market knowledge (Mathews and Healy, 2008), to easier communication with customers and customer support (Morgan-Thomas, 2009, Wang et al., 2011).

Overall, for service firms, ICT use variables are statistically significant in a smaller number of cases as compared to results for the manufacturing sector. This finding does not seem to be in line with the expectations that ICT use will have a stronger effect on export in the service sector (Freund and Weinhold, 2004). They are more consistent with a study of the ways in which service firms are using Internet that has revealed no difference between them and manufacturing firms, concluding that the interactive potential of Internet seems not yet to be realised (Arnott and Bridgewater, 2002). A study by Clarke (2008) also found no evidence that Internet access affects service firms more than manufacturing, offering as a possible explanation the composition of service firms in the sample. This might also explain our results. First, in our data sets, the firms from ICT-producing industries were excluded and we can expect these firms to be the ones internationalising strongly; for example, one of the fastestgrowing categories of services in the US trade over 1995-1999 was computer and data 
processing (Freund and Weinhold, 2002). And second, some services need a physical interaction with clients and cannot be delivered digitally which means exporting is not a viable option. In addition to this, a key characteristic of services is their intangibility. When this is combined with the often complex technical nature of professional services, clients might not have the means to evaluate the quality of advice they purchase, thus evaluating them on surrogates such as brand reputation, country of origin and relational skills that an individual service provider shows during the delivery (La et al., 2005). In such cases, it is not the technological infrastructure that determines the export performance of firms but the skilful ways in which technology is deployed (Samiee, 1998), for which we cannot directly control in our model.

\section{Conclusions}

This study shows that the relationship between different ICT uses and export propensity of larger firms differs among sectors as well as countries. Whereas in some of the countries e-sales are being positively associated with the probability of exporting for firms from both sectors, having a website is only relevant for manufacturing firms and broadband-Internet-enabled employees are only relevant for service firms. In addition to this, the relationship between ICT use and export propensity does not hold for all of the countries included in the analysis. All of this suggests heterogeneity amongst countries and specific characteristics of service firms. Due to a unique research setting, the resulting estimates are fully comparable across countries. Although it is difficult to determine the direction of causality - it is possible that observed correlation is caused by reverse causality - the empirical results suggest that ICT use might affect export performance. That is, the results are robust to the inclusion of many variables to control for other firm characteristics that might affect ICT use and exporting activity and are also robust to the use of lagged values for most of the independent variables. This study enriches our understanding of the determinants of export behaviour, specifically of the role ICT plays in supporting export activity of larger firms. Our research findings add to the existing literature in three ways.

First, we have contributed to the international business and international trade literature by adding different aspects of the use of ICT to the study of export performance determinants. Our findings are consistent with the idea that theory should strive to adapt to the changes the developments in ICT are bringing. Our results suggest that it is not only the size of the firm, previous exports or innovation that are relevant for export participation but that the firms in a range of countries can build their competitive advantage by ICT use. We are also addressing some of the disadvantages of previous studies. We explore the simultaneous effect of the different uses of ICT, including internet use as well as online sales. We also control for a range of other firm characteristics, including human capital and innovation activities. 
Second, we have contributed to the scarce literature on the role of ICT in export performance of service firms. Given the specific characteristics of service firms when operating in the international markets, a question arises whether the same determinants of export performance apply as for manufacturing firms. Also, expectations were created about internet being able to support the previously unfeasible trade in services that do not need physical contact. Internet was thus expected to have a stronger effect on export of services when compared to manufacturing. Our study has shown that not all of the export determinants that are found relevant for manufacturing firms also matter for service firms; for example, product innovation. Also, we could found no evidence that various uses of ICT are statistically significant in more cases as compared to results for manufacturing firms - in fact it was the opposite. Having a website does not seem to be relevant for export probability of service firms.

Third, only rarely do studies on determinants of export performance use data from more than one country and include European countries beyond the ones most often studied, with different economic, technological and cultural settings. Our study is based on a large firm-level data set for 11 European countries and detailed and country specific adjustments to the datasets were made to achieve comparable data to which identically specified empirical model was applied. The opportunity to examine empirical results that are fully comparable across countries gives us the advantage of getting an indication of the external validity of the models. In our results we observe differences between the countries with regards to the set of influential determinants of export performance. Since we can eliminate methodological heterogeneity across countries as a possible reason for these differences, there are other possible explanations left. The first one is differences in sampling. Differences do exist in the sampling strategies of statistical offices that underlie some of the survey data used in our study but they lead to a data set of larger firms with higher performance in most of the countries. The other possible reason for mixed findings is the differences in countryspecific macroeconomic factors, such as institutions or region specific shocks. The institutional setting was already found to influence the role of innovative capabilities in shaping export performance. Another explanation could be the differences across countries in their levels of development that lead to different determinants of export activity not all of which were captured in the analysed model. This study is the first to show that the variation exists between countries in the empirical evidence, thus opening up a relevant question: what country characteristics can help explain the differences in the role ICT use plays in export performance. Possible explanations will have to take into consideration not only countries' own factors, like telecommunication infrastructure, but also that of the trade partners since willingness to engage in e-commerce differs between countries. Further research in this area is needed and is of special interest to the policy makers. 


\section{References}

Akerman, A., Gaarder, I., Mogstad, M. (2015) "The Skill Complementarity of Broadband Internet", The Quarterly Journal of Economics, Vol. 130, No. 4, pp. 1781-1824, doi: 10.1093/qje/qjv028.

Arenius, P., Sasi, V., Gabrielsson, M. (2005) "Rapid internationalisation enabled by the Internet: The case of a knowledge intensive company", Journal of International Entrepreneurship, Vol. 3, No. 4, pp. 279-290, doi: 10.1007/s10843006-7856-X.

Arnott, D.C., Bridgewater, S. (2002) "Internet, interaction and implications for marketing”, Marketing Intelligence \& Planning, Vol. 20, No. 2, pp. 86-95, doi: 10.1108/02634500210418509.

Bartelsman, E., Van Leeuwen, G., Polder, M. (2016) "CDM using a cross-country micro moments database", Economics of Innovation and New Technology, Vol. 26, No. 1-2, pp. 168-182, doi: 10.1080/10438599.2016.1202517.

Bernard, A. B., Jensen, J. B. (2004) "Why Some Firms Export", The Review of Economics and Statistics, Vol. 86, No. 2, pp. 561-569, doi: 10.1162/ 003465304323031111.

Berthon, P., Pitt, L., Katsikeas, C.S., Berthon, J.P. (1999) "Virtual Services Go International: International Services in the Marketspace", Journal of International Marketing, Vol. 7, No. 3, pp. 84-105, doi: 10.1108/03090569910274465.

Bharadwaj, A.S. (2000) "A Resource-Based Perspective on Information Technology Capability and Firm Performance: An Empirical Investigation", MIS Quarterly, Vol. 24, No. 1, pp. 169-196, doi: 10.2307/3250983.

Bhatt, G. D., Grover, V. (2005) "Types of Information Technology Capabilities and Their Role in Competitive Advantage: An Empirical Study", Journal of Management Information Systems, Vol. 22, No. 2, pp. 253-277, doi: 10.1080/ 07421222.2005.11045844.

Borchert, I., Gootiiz, B., Mattoo, A. (2013) "Policy barriers to international trade in services: evidence from a new database", The World Bank Economic Review, Vol. 28, No. 1, pp. 162-188, doi: 10.1093/wber/lht017.

Civic Consulting (2011) Consumer market study on the functioning of e-commerce and Internet marketing and selling techniques in the retail of goods, Berlin: Executive Agency for Health and Consumers.

Clarke, G. R. (2008) "Has the internet increased exports for firms from low and middle-income countries?", Information Economics and Policy, Vol. 20, No. 1, pp. 16-37, doi: 10.1016/j.infoecopol.2007.06.006.

Conti, G., Lo Turco, A., Maggioni, D. (2014) "Spillovers through backward linkages and the export performance of business services. Evidence from a sample of Italian firms", International Business Review, Vol. 23, No. 3, pp. 552-565, doi: 10.1016/j.ibusrev.2013.09.003. 
Filipescu, D.A., Prashantham, S., Rialp, A., Rialp, J. (2013) "Technological Innovation and Exports: Unpacking Their Reciprocal Causality", Journal of International Marketing, Vol. 21, No. 1, pp. 23-38, doi: 10.1509/jim.12.0099.

Francois, J., Hoekman, B. (2010) "Services trade and policy", Journal of Economic Literature, Vol. 48, No. 3, pp. 642-692, doi: 10.1257/jel.48.3.642.

Freund, C., Weinhold, D. (2002) "The Internet and International Trade in Services", The American Economic Review, Vol. 92, No. 2, pp. 236-240, doi: $10.1257 / 000282802320189320$.

Freund, C., Weinhold, D. (2004) "The effect of the Internet on international trade", Journal of International Economics, Vol. 62, No. 1, pp. 171-189, doi: 10.1016/ s0022-1996(03)00059-x.

Gabrielsson, M., Gabrielsson, P. (2011) "Internet-based sales channel strategies of born global firms", International Business Review, Vol. 20, No. 1, pp. 88-99, doi: 10.1016/j.ibusrev.2010.05.001.

Ganotakis, P., Love, J.H. (2011) "R\&D, product innovation, and exporting: evidence from UK new technology based firms", Oxford Economic Papers, Vol. 63, No. 2, pp. 279-306, doi: 10.1093/oep/gpq027.

Gao, G.Y., Murray, J.Y., Kotabe, M., Lu, J. (2010) “A 'strategy tripod' perspective on export behaviors: Evidence from domestic and foreign firms based in an emerging economy", Journal of International Business Studies, Vol. 41, No. 3, pp. 377-396, doi: 10.1057/jibs.2010.32.

Gashi, P., Hashi, I., Pugh, G. (2014) "Export behaviour of SMEs in transition countries", Small Business Economics, Vol. 42, No. 2, pp. 407-435, doi: 10.1007/ s11187-013-9487-7.

Greenaway, D., Kneller, R. (2007) "Firm heterogeneity, exporting, and foreign direct investment", The Economic Journal, Vol. 117, No. 517, pp. 134-161, doi: 10.1111/j.1468-0297.2007.02018.x.

Higon, D. A., Driffield, N. (2011) "Exporting and innovation performance: Analysis of the annual Small Business Survey in the UK", International Small Business Journal, Vol. 29, No. 1, pp. 4-24, doi: 10.1177/0266242610369742.

Jaklič, A., Ćirjaković, J., Chidlow, A. (2012) "Exploring the effects of international sourcing on manufacturing versus service firms", The Service Industries Journal, Vol. 32, No. 7, pp. 1193-1207, doi: 10.1080/02642069.2012.662496.

Jones, M.V., Crick, D. (2004) 'Internationalising high-technology-based UK firms' information-gathering activities", Journal of Small Business and Enterprise Development, Vol. 11, No. 1, pp. 84-94, doi: 10.1108/14626000410519128.

La, V.Q., Patterson, P.G., Styles, C.W. (2005) "Determinants of export performance across service types: a conceptual model", Journal of Services Marketing, Vol. 19, No. 6, pp. 379-391, doi: 10.1108/08876040510620157.

Leonidou, L. C., Katsikeas, C. S. (2010) "Integrative assessment of exporting research articles in business journals during the period 1960-2007", Journal of 
Business Research, Vol. 63, No. 8, pp. 879-887, doi: 10.1016/j.jbusres. 2010.01.005.

Lohrke, F.T., Franklin, G.M., Frownfelter-Lohrke, C. (2006) "The Internet as an Information Conduit: A Transaction Cost Analysis Model of US SME Internet Use", International Small Business Journal, Vol. 24, No. 2, pp. 159-178, doi: $10.1177 / 0266242606061838$.

Mathews, S., Healy, M. (2008) "'From garage to global': the internet and international market growth, an SME perspective", International Journal of Internet Marketing and Advertising, Vol. 4, No. 2-3, pp. 179-196, doi: 10.1504/ ijima.2008.017021.

Mathews, S., Healy, M.J. (2007) "The Internet and information capability reduces perceived risk of internationalisation: An Australian SME perspective", International Journal of Organisational Behaviour, Vol. 12, No. 1, pp. 71-87.

Matzler, K., Grabher, C., Huber, J., Füller, J. (2013) "Predicting new product success with prediction markets in online communities", $R \& D$ Management, Vol. 43, No. 5, pp. 420-432, doi: 10.1111/radm.12030.

Melitz, M.J. (2003) "The Impact of Trade on Intra-Industry Reallocations and Aggregate Industry Productivity”, Econometrica, Vol. 71, No. 6, pp. 16951725, doi: 10.3386/w8881.

Morgan-Thomas, A. (2009) "Online activities and export performance of the smaller firm: a capability perspective", European Journal of International Management, Vol. 3, No. 3, pp. 266-285, doi: 10.1504/ejim.2009.026992.

Morgan-Thomas, A., Jones, M.V. (2009) "Post-entry Internationalization Dynamics", International Small Business Journal, Vol. 27, No. 1, pp. 71-97, doi: 10.1177/ 0266242608098347.

OECD (2013) Exploring Data-Driven Innovation as a New Source of Growth: Mapping the Policy Issues Raised by "Big Data", Paris: OECD Publishing.

Overby, J.W., Min, S. (2001) "International supply chain management in an Internet environment: A network-oriented approach to internationalization", International Marketing Review, Vol. 18, No. 4, pp. 392-420, doi: 10.1108/eum0000000005933.

Pla-Barber, J., Ghauri, P.N. (2012) "Internationalization of service industry firms: understanding distinctive characteristics", The Service Industries Journal, Vol. 32, No. 7, pp. 1007-1010, doi: 10.1080/02642069.2012.662498.

Prasad, V.K., Ramamurthy, K., Naidu, G.M. (2001) "The Influence of InternetMarketing Integration on Marketing Competencies and Export Performance", Journal of International Marketing, Vol. 9, No. 4, pp. 82-110, doi: 10.1509/ jimk.9.4.82.19944.

Raymond, L., Bergeron, F., Croteau, A.-M., St-Pierre, J. (2015) "Developing Absorptive Capacity through e-Business: The Case of International SMEs", Journal of Small Business Management, Vol. 53, No. S1, pp. 75-94, doi: 10.1111/ jsbm. 12192 . 
Reuber, A.R., Fischer, E. (2011) "International entrepreneurship in internet-enabled markets", Journal of Business Venturing, Vol. 26, No. 6, pp. 660-679, doi: 10.1016/j.jbusvent.2011.05.002.

Rhee, J. H. (2005) "The internet era and the international expansion process: the moderating role of absorptive capacity", MIR: Management International Review, Vol. 45, No. 3, pp. 277-306.

Ricci, L.A., Trionfetti, F. (2012) "Productivity, Networks, and Export Performance: Evidence from a Cross-country Firm Dataset", Review of International Economics, Vol. 20, No. 3, pp. 552-562, doi: 10.1111/j.1467-9396.2012.01038.x.

Rodríguez, A., Nieto, M.J. (2012) "The internationalization of knowledge-intensive business services: the effect of collaboration and the mediating role of innovation", The Service Industries Journal, Vol. 32, No. 7, pp. 1057-1075, doi: 10.1080/02642069.2012.662493.

Roper, S., Love, J.H., Hígon, D.A. (2006) “The determinants of export performance: Evidence for manufacturing plants in Ireland and Northern Ireland", Scottish Journal of Political Economy, Vol. 53, No. 5, pp. 586-615, doi: 10.1111 /j.14679485.2006.00396.x.

Rust, R.T., Huang, M.-H. (2014) "The service revolution and the transformation of marketing science", Marketing Science, Vol. 33, No. 2, pp. 206-221, doi: 10.1287/mksc.2013.0836.

Samiee, S. (1998) "Exporting and the Internet: a conceptual perspective", International Marketing Review, Vol. 15, No. 5, pp. 413-426, doi: 10.1108/ 02651339810236452.

Serra, F., Pointon, J., Abdou, H. (2012) "Factors influencing the propensity to export: A study of UK and Portuguese textile firms", International Business Review, Vol. 21, No. 2, pp. 210-224, doi: 10.1016/j.ibusrev.2011.02.006.

Sinkovics, N., Sinkovics, R. R., Jean, R.-J. B. (2013) "The internet as an alternative path to internationalization?", International Marketing Review, Vol. 30, No. 2, pp. 130-155, doi: 10.1108/02651331311314556.

Sousa, C.M.P., Martinez-Lopez, F.J., Coelho, F. (2008) "The determinants of export performance: A review of the research in the literature between 1998 and 2005", International Journal of Management Reviews, Vol. 10, No. 4, pp. 343-374, doi: 10.1111/j.1468-2370.2008.00232.x.

Sultan, F., Rohm, A.J. (2004) "The evolving role of the internet in marketing strategy: an exploratory study", Journal of interactive Marketing, Vol. 18, No. 2, pp. 6-19, doi: 10.1002/dir.20003.

Wagner, J. (2007) "Exports and Productivity: A Survey of the Evidence from Firmlevel Data", World Economy, Vol. 30, No. 1, pp. 60-82, doi: 10.1111/ j.14679701.2007.00872.x.

Wakelin, K. (1998) "Innovation and export behaviour at the firm level", Research Policy, Vol. 26, No. 7-8, pp. 829-841, doi: 10.1016/s0048-7333(97)00051-6. 
Wang, M.C.-H., Khalil, S., Blankson, C., Cheng, J.M.-S. (2011) "The Influence of the Provision of Online Channel Functions on Exporting Channel Performance: The Moderating Effect of International Experience", Journal of Global Marketing, Vol. 24, No. 2, pp. 125-135, doi: 10.1080/08911762.2011.558811.

Wang, Y., Cao, W., Zhou, Z., Ning, L. (2013) "Does external technology acquisition determine export performance? Evidence from Chinese manufacturing firms", International Business Review, Vol. 22, No. 6, pp. 1079-1091, doi: 10.1016/j. ibusrev.2013.02.009.

Yang, Y., Mallick, S. (2014) "Explaining cross-country differences in exporting performance: The role of country-level macroeconomic environment", International Business Review, Vol. 23, No. 1, pp. 246-259, doi: 10.1016/j. ibusrev.2013.04.004.

Yi, J., Wang, C. (2012) "The decision to export: Firm heterogeneity, sunk costs, and spatial concentration", International Business Review, Vol. 21, No. 5, pp. 766781, doi: 10.1016/j.ibusrev.2011.09.001.

Yi, J., Wang, C., Kafouros, M. (2013) "The effects of innovative capabilities on exporting: Do institutional forces matter?", International Business Review, Vol. 22, No. 2, pp. 392-406, doi: 10.1016/j.ibusrev.2012.05.006. 


\title{
Korištenje ICT-a kao odrednice izvozne djelatnosti u proizvodnim i uslužnim tvrtkama na primjeru više država
}

\author{
Patricia Kotnik ${ }^{1}$ Eva Hagsten ${ }^{2}$
}

\begin{abstract}
Sažetak
Korištenje ICT-a temeljito mijenja međunarodno poslovanje. Istraživanje nastoji proširiti naše razumijevanje odrednica izvoznih rezultata ispitivanjem odnosa između različitih primjena ICT-a i izvoznih aktivnosti tvrtki za niz europskih zemalja $i$ to za uzorak većih proizvođača kao i poduzeća za pružanje usluga. Probit-regresija koristi se za ispitivanje da li je vjerojatnije da poduzeća koja imaju web stranicu $i$ podržavaju mrežne transakcije ili imaju veći postotak zaposlenika s pristupom širokopojasnom internetu više izvoze od sličnih poduzeća koje nemaju te karakteristike, kontrolirajući široki raspon karakteristika poduzeća. Ova studija temelji se na usklađenim podacima na razini poduzeća koje pružaju statistički uredi 11 zemalja EU-a na koje se primjenjuje isti empirijski model, pružajući rezultate koji su potpuno usporedivi u svim zemljama. Rezultati ukazuju na heterogenost među zemljama i specifična obilježja uslužnih poduzeća. Dok se u nekim zemljama e-prodaja pozitivno povezuje s vjerojatnosti izvoza tvrtki iz oba sektora, web stranica je relevantna samo za proizvodne tvrtke, a osposobljenost zaposlenika za korištenje širokopojasnog interneta samo za poduzeća za pružanje usluga. Uporaba ICT-a u velikom broju zemalja nije od osobite važnosti za izvoz poduzeća, te se otvara pitanje koja su to obilježja zemlje koja mogu pomoći objasniti razlike u ulozi korištenja ICT-a u postizanju rezultata izvoza.
\end{abstract}

Ključne riječi: internet, ICT, e-prodaja, izvoz, poduzeća za pružanje usluga

JEL klasifikacija: F23, F14, O33

1 Docent, Faculty of Economics, University of Ljubljana, Kardeljeva ploscad 17, 1000 Ljubljana, Slovenija. Znanstveni interes: poduzetništvo, poslovna ekonomija. Tel.: +38615892 579. Fax: +38615892 698.E-mail: patricia.kotnik@ef.uni-lj.si (osoba za kontakt).

2 Stručnjakinja za statistiku, Statistics Sweden, Box 24300, 10451 Stockholm, Švedska (nova grupacija: Swedish Agency for Economic and Regional Growth, Box 4044, 10261 Stockholm, Švedska). 